\title{
The Efficacy of Corrective Feedback on L2 Writings of EFL Students
}

Senanur ÇINAR

Istanbul Gelişim University

\begin{abstract}
Errors have been perceived as problems within the process of teaching and learning a language. However, especially in writing, learners are able to benefit from their errors with the help of corrective feedback. The purpose of this study is to investigate the effectiveness of explicit corrective feedback in Turkish EFL learners' writing. The participants of the study were 43 intermediate level Turkish EFL students at a private university in Turkey. There were one experimental, 21 students, and one control group, 22 students. As the data collection both groups were administered a pre-test, a post-test and a delayed post-test as a paper and pencil tests. The experimental group received explicit corrective feedback with extended comments on their errors, and the control group received no feedback. Their errors were only underlined without providing correction. The number of errors that each group made in the writings was compared to each other. In order to ensure the reliability and validity, the participants were administered a 5 Likert scale questionnaire after the writing sessions. The results revealed that the experimental group who received explicit corrective feedback made fewer errors than the control group who did not receive feedback on their L2 writings. Besides that, the experimental group made fewer mistakes in their tests compared to the previous ones. Thus, the findings of the questionnaire revealed that students had a positive view about corrective feedback their L2 writings especially if it has extended comments.
\end{abstract}

Keywords: L2 writing, corrective feedback, explicit feedback, error correction, feedback, EFL, error, correction

\section{Introduction}

Throughout the history of teaching writing skill in second language (L2) several debates have come up in terms of the effectiveness of error correction. However, both teachers and L2 students are able to benefit from written errors with the help of corrective feedback (CF). Feedback is the explanation provided by the teacher about the performance of the student in an aim to improve student's learning (Voerman, Meijer, Korthagen \& Simons, 2012). The aim of feedback is to teach skills to students so that they can improve their language proficiency to an extent which they are aware of what is expected from them as learners, and can produce language with minimal errors. Russel and Spada (2006) stated that it means any type of feedback provided to a learner from any source that includes evidence of learner error of language form. Learners need to be provided with constant feedback and correction in their writings in order to facilitate their writing skills and minimize their errors to the least. Therefore, written corrective feedback is very significant within this process. Moreover, the kind of feedback that learners need when they make errors in writing is significant as well. When checking students' writings, teachers often see that the process of $L 2$ writing requires more effort. At that point the type of feedback that needs to be provided becomes essential. Different learning styles, language levels, ages and purpose of learning are determining factors when providing feedback to language learners.

\section{Literature Review}

To date, several studies have been conducted on corrective feedback in order to determine which types of corrective feedback are effective in English as a foreign language (EFL) classrooms. However, the issue of which is the most effective one(s) is still debatable. Truscott $(1996 ; 1999 ; 2007)$ claimed that there is no rational evidence that proves the usefulness of error correction in students' writing. He stated that corrective feedback is unable to observe to what extent learners have acquired language and also it is harmful for learners to acquire the language. On the other hand, several scholars have done studies against the claim of Truscott and found out many evidences that prove the ultimate benefit of CF. They stated that learners need to be provided with corrections after making errors so that they can acquire language in a more useful 
way. Moreover, with the help of explicit corrective feedback learners get the opportunity to focus on their errors and come to understand what kind of errors they need to correct. It allows learners to self-repair (Lyster, 1997) and it becomes easier for learners to interpret the feedback that they have received.

The efficacy of corrective feedback has been tested in several ways. Carroll and Swain (1993) conducted a study including 100 Spanish adult ESL learners whose level was low elementary. The aim was to teach the structure of dative verbs. They had five different groups $-\mathrm{A}, \mathrm{B}, \mathrm{C}, \mathrm{D}$ and $\mathrm{E}$ - which were divided into groups according to the type of feedback they received once they made an error. The participants were provided with two feedback sessions following the practice of recall that included production tasks after each feedback's session. Group B-C and D received implicit feedback such as pointing out their errors by stating that they made mistake or recasting. Group A received explicit metalinguistic feedback when they made errors and group $E$ with no feedback as the control group. The results of the study indicated that all group $A, B, C$ and D outperformed group E, the control group. Moreover, group A, which were provided with direct explicit feedback was concluded to have the best output among the others. Later on Carroll conducted a study in 2001, without Swain this time, on the efficacy of explicit feedback in writing. The participants included adult low-intermediate ESL students and the aim was to form nouns from verbs. The participants were divided into groups as they were previously did in the previous study of Carroll and Swain (1993). Learners were given elicited verb and noun constructions within a sentence format. They were provided with different types of corrective feedback to their writings. Eventually, Carroll resulted that all types of feedback helped them to learn the target knowledge, yet only the students who were provided with explicit metalinguistic corrective feedback - group A- were able to generalize the form whereas the others which were provided with implicit feedback did not work in generalization. Therefore, Carroll concluded that among the others, explicit feedback enabled learners to improve L2 knowledge.

Pérez, Fuentealba, Barra, Rojas and Cisternas (2012) conducted a research to examine the impact of feedback on content and structure in writing tasks of EFL students. Participants included three students and a female teacher in the first study. In the second study there were three students and a male teacher. They used structured interview which consisted of six questions in learners' target language, a writing task and a document analysis methodology. The purpose of the interview was to examine learners' opinions and preferences about receiving feedback rather than testing their English knowledge. The document analysis was carried out by examining a collection of students' writing tasks which was done both before and during the examination. The study revealed that students felt motivated to write the task for the second time once they were provided with explicit feedback in terms of content and organization. In the interviews, most of the participants preferred receiving written feedback so that they could be able to comprehend their errors better. Additionally, students' writings seemed to be more improved when they received comments in target language. In 2013 Ulgu, Sari \& Griffiths investigated teachers' perceptions of corrective feedback in Turkey. They interviewed 51 non-native Turkish teachers of English with different experiences in several state and private universities in Turkey in an EFL context asking them about when and how corrective feedback is required in both oral and written skills. The results indicated that teachers want to correct learners' errors, and that they are in favor of immediate written and oral correction. As another example of study about teachers' perceptions on corrective feedback Kirgoz and Agcam (2015) interviewed with 36 teachers from various grades in state primary schools. They asked teachers their opinions about the efficacy of corrective feedback and its varieties, about their attitude toward learners' errors and how and when errors should be corrected or whether these errors should be corrected. They resulted that elicitation is the most effective way in correcting errors, following the repetition CF as another effective type. It was concluded from the interviews that explicit correction is an effective CF type used by EFL teachers. In 2016 Chen, Nassaji and Liu conducted a study to examine learners' perceptions and preferences on written corrective feedback in an EFL setting. They interviewed 64 intermediate, advanced-intermediate and advanced English learners in a university. The results showed that most of the students were in favor of error correction despite the fact that they were objective about the role of explicit grammar instruction. Moreover, they strongly preferred detailed comments on both content and grammar of their writings.

As another example of studies which resulted with the positive effect of CF on learners' language competence was conducted by Varnosfadrani and Basturkmen in 2009. They especially focused on explicit and implicit correction and their efficacy in the acquisition of grammatical features on 56 intermediate level Iranian learners of English. The participants were asked to read a text and retell it during an interview. During the interview they were corrected implicitly with recasts or explicitly once they made grammatical errors. The participants had tailor-made tests which were constructed according to the errors that they had made. Their test results were statistically analyzed and they indicated that the learners who 
received explicit feedback outperformed those who were corrected implicitly once they made errors. Therefore, the study pointed out the significance of explicit CF in the improvement of learners' metalinguistic knowledge in language learning.

There was a little or no difference between implicit and explicit feedback within some research (Kim \& Mathes, 2001; Bitchener \& Knoch, 2009; Gholami \& Talebi, 2012). In $2001 \mathrm{Kim}$ and Mathes examined the efficacy of implicit and explicit feedback on 20 Korean speakers' use of dative alternation in English. They aimed to find out which one is more useful for the learners. The learners were divided into groups according to the CF type that they received and were trained in dative alternation in the form of one structural change. One group was provided with explicit metalinguistic feedback when they made errors while the other one with implicit error correction in the form of a sentence recast in the correct form. Posttests showed no difference between the groups. Similarly, Bitchener and Knoch investigated the effectiveness of different types of CF over a 10-month period, found out that each of the groups which received one of the feedback performed better than the control group; however, there was no difference in effectiveness between the treatment groups. Gholami and Talebi (2012) conducted a case study which included 45 elementary female learners of English in Iran. The aim was to find out the effect of implicit and explicit feedback on EFL learners' grammatical accuracy especially on regular past tense. These participants were assigned into one control and two experimental groups. The experimental groups were provided recast and explicit feedback with picture description tasks and the control group did not receive any feedback. Learners' acquisition of regular past tense -ed was measured with their metalinguistic knowledge and verbal imitation tests. As the analysis of data they used ANOVA and resulted that experimental groups who were provided with explicit feedback did slightly better than the control group. The results also indicated that there were no much differences between the two types of feedback, implicit and explicit, in terms of learners' achievement in an EFL context.

As it is presented within the previous studies, most of students seemed to benefit from corrective feedback on their L2 works. Yet, the type of feedback that would be the best for language learners is not perceived as a single one. In fact, every language learner may perefer different type of corrective feedback related to their age, level, purpose, etc. To the best of my knowledge, there are a few studies conducted in Turkey on the efficacy of corrective feedback on L2 writings of EFL students. With respect to this need, present study aims to examine the efficacy of corrective feedback on Turkish EFL learners' use of indefinite and definite articles in L2 writing.

\section{Research Questions}

\section{To what extent is corrective feedback effective in Turkish EFL learners' L2 writings?}

2. What are Turkish EFL learners' perceptions on corrective feedback that they receive in their L2 writings?

\section{Methodology}

\section{Setting and Participants}

The present study was conducted at an English preparatory school of a selected private university in Istanbul, Turkey. The study was carried in the researcher's own teaching environment. In this university, the students are supposed to take a proficiency exam before they start studying their departments. All students start studying their departments when they successfully complete A2, B1, B1+ and B2 levels. They are administered an achievement test at the end of each level which lasts 8 weeks. There is no such a thing as failing the level, yet when they finish all levels, their total score out of 4 levels must be 70 or higher grade in total in order to start their departments.

In this preparatory school, there are 34 classes and 764 students. The present study involves two B1 level classes, which consists of 43 students (19 females and 24 males) aged between 18-22.

At the time of the study students had just finished A2 level and started B1 level. Each student has different background English knowledge; some of the students just started learning English as a foreign language in this preparatory program, and some of them had a little previous knowledge of English.

The participants of this study had taken A2 level writing classes, and had been taught the target structures before the treatment. There are two classes which will be called in the study as the experimental group, consisting 22 students (10 females, 12 males) receiving explicit corrective feedback and the control group consisting 21 students ( 9 females and 12 males) with no feedback on their L2 writing. These participants were randomly assigned to groups to receive different treatments within the study. The reason why B1 level students were chosen as the participants is that they had just 
completed A2 level and they were expected to make more errors since they were new to learn English as a foreign language, and also because they do not have enough exposure to the target language and have difficulty in producing what they have learned.

\section{Data Collection Instruments}

In order to obtain data about the efficacy of corrective feedback on EFL learners' $L 2$ writings, two types of instruments were used as data source. The first data type was a paper and pencil test type consisting a pre-test, a post-test, and a delayed post-test. Students were asked to write three different writings in different weeks. Both experimental and control group were administered to the same tasks within same weeks. For the each writing they were asked to write one paragraph with the length of 120 words in 30 minutes. The second data collection instrument was a questionnaire with close-ended questions for the students. This quantitative data was used in order to collect data about EFL learners' perceptions of corrective feedback on their L2 writings.

\section{Questionnaire}

The present study administered a close-ended questionnaire in which there are multiple choices and 5 Likert scale ranging from strongly disagree to strongly agree. This quantitative data was used in order to examine the general views and perceptions of the students for corrective feedback on their $\mathrm{L} 2$ writings. The questionnaire was posed to both experimental and control group after the treatment. The design of the questionnaire (Amrhein \& Nassaji, 2010) was adapted to the study with some changes. It started with demographic questions followed by their English level question. The questionnaire was extensively revised to promote its readability and transparency. The teacher translated the questions into students' first language, Turkish, when needed with the back-translation method. Therefore, the teacher translated the questions into English back to ensure that it is equivalent enough to compare the results of the data.

\section{Writing Assignments}

Students were expected to write all tests in single 120 words length-paragraph using simple past tense which they had been taught previously in their writing classes. In the first writing assignment, which was considered as the pre-test, they were expected to write about their holiday experience. They were also supplied with content ideas in their writings.

For the post-test, students were assigned to write a letter to their friend explaining their last weekend. They were again supplied with content ideas. Finally, in the delayed post-test students were asked to write a short narrative story with the information provided.

\section{Procedure}

The participants were informed that they would be a part of the study. While giving feedback on the writings, the focus was on the target structure as they had just learned them in their writing classes. The writing sessions were held in classrooms and lasted 25-30 minutes. The pre-test was given a week prior to starting the treatment in order to ensure the homogeneity and students' proficiency in L2 writing using the target structure. As stated above, students were assigned to write a paragraph about one of their holiday experiences. They wrote a 120 words length-paragraph using target structure 25-30 minutes. Between the process of pre and post-test the experimental group was given explicit corrective feedback treatments in their writings within the classroom. The post-test was given after both experimental and control group completed their first assignment. The procedure was the same with the pre-test. Yet, this time the experimental group was provided with explicit corrective feedback in their writings. Their errors were identified, corrected and given detailed explanations by the teacher. Students were provided with constant explicit corrective feedback on their L2 writings during writing sessions. The control group received no feedback on their writings; their errors were only underlined by the teacher with no correction. Therefore, they needed to understand and correct their errors by themselves after being informed by the teacher that they had made errors.

After the experimental group received explicit corrective feedback and the control group received no feedback, one week later the students were given a delayed post-test to write a short narrative story in 25-30 minutes. The purpose of giving the same structure was to investigate if students made the same errors and if they could benefit from the type of feedback that they had received when they made errors. 
After students completed pre-test, post-test and delayed post-test, the participants were administered the questionnaire the week following. It aimed to find out students' perceptions on the corrective feedback that they had received on their writings. When the whole procedure ended, students' number of errors in their writings in each three sessions and answers on the questionnaire were counted.

\section{Data Analysis}

For the analysis of writing assignments, the numbers of errors for both experimental and control group were counted in order to analyze if there occurred and changes after the treatments. The primary purpose of the questionnaire was to elicit students' perceptions of written corrective feedback. Therefore, close-ended questions with multiple choice or Likert scale formats were used to elicit main tendencies of students. In order to analyze the data, the numbers of students to questionnaire responses were counted. Both descriptive and inferential statistics were conducted to examine statistically significant differences among three proficiency levels. In the following chapter, both experimental and control group's ratio of errors after receiving different types of feedback on their writings and findings of the quantitative questionnaire will be presented.

\section{Results}

\section{Finding of Writing Assignments}

Both experimental and control group were assigned to complete writing tasks which consists pre, post and delayed posttests. The feedback was given to the experimental group's writing assignments as illustrated below;

\section{S: "I goed to Antalya with my family."}

T: "I went to Antalya with my family, 'go' is an irregular verb."

For the control group the errors were only pointed to be reformed by the learner as given below:

\section{S: "We swimmed in the sea."}

\section{T: "We swimmed in the sea."}

Table 1 shows the number of errors that two groups made in the use of target structure, simple past tense. The number of errors were presented as total for each three assignments.

Table 1. Number of Errors That Students Made in Writing Assignments

\begin{tabular}{l|l|l|l} 
& Pre-Test & Post-Test & Delayed Post-Test \\
\hline Control Group & 139 & 133 & 137 \\
\hline Experimental Group & 144 & 113 & 97
\end{tabular}

As showed above, there were no significant differences in control group's number of errors, in fact, there was an increase in the number of errors. Only underlying the error did not work for them to correct their errors. They kept making the same errors in the target structure. Most of them could not understand what their mistakes were, and couldn't correct them. This could be because they were ineffective in self-corrertion due to their English level.

However, as illustrated above, after the treatments that experimental group received explicit corrective feedback, students benefited from the corrected errors and explanations. There were significant changes in the number of errors that the experimental group made in their writings. As the target structure was the same for each assignment, they benefited from the previous feedback that the teacher provided, and as a result there was a spectacular decrease in the number of errors.

\section{Findings of Questionnaire}


Both experimental and control group were administered the quantitative questionnaire after completing the writing assignments. The results of the questionnaire were divided into 10 categories; participants' perceptions of grammar instruction, error correction in English, their preferences of error correction types, their opinions on teachers' error correction priority, preferences of error correction techniques, their responses to extended comments on writing assignments, preferences of comment types, responses to corrected errors, preferences on the timing of grammatical error correction, and finally participants' preferences on the timing of content and organizational error correction.

The first question was asked students in order to find out their general perceptions of grammar instruction in writing classes. The participants' responses are presented as percentages in Table 2. Table 2 indicates that most students were in favor of the necessity of grammar instruction in their writing classes and believed that learning grammar would improve their writing skills in English. However, they expressed less positive opinions on explicit grammar instruction, as illustrated in the results of statements d, e and f. Moreover, the statement "I like studying English grammar" received the lowest ratings. On the other hand, the statement "I think that language practice in real contexts is more important than grammar instruction in the classroom." was the one that received very positive ratings.

Table 2. Students' perceptions of grammar instruction in writing classes

\begin{tabular}{|c|c|c|c|c|c|}
\hline Questionnaire Item & Strongly Disagree & Disagree & Neutral & Agree & Strongly Agree \\
\hline $\begin{array}{l}\text { Grammar instruction } \\
\text { is essential for } \\
\text { mastering the writing } \\
\text { of English. }\end{array}$ & $7 \%$ & $9 \%$ & $7 \%$ & $42 \%$ & $35 \%$ \\
\hline $\begin{array}{l}\text { Study of grammar } \\
\text { improves my writing } \\
\text { skill of English. }\end{array}$ & $6 \%$ & $12 \%$ & $12 \%$ & $42 \%$ & $27 \%$ \\
\hline $\begin{array}{l}\text { I believe that my } \\
\text { English writing will } \\
\text { improve quickly if I } \\
\text { study and practice } \\
\text { English grammar }\end{array}$ & $4 \%$ & $19 \%$ & $21 \%$ & $33 \%$ & $23 \%$ \\
\hline $\begin{array}{l}\text { I like studying } \\
\text { English grammar }\end{array}$ & $11 \%$ & $14 \%$ & $16 \%$ & $28 \%$ & $31 \%$ \\
\hline \multicolumn{6}{|l|}{ Table2 Continued } \\
\hline $\begin{array}{l}\text { I need more } \\
\text { grammar instruction } \\
\text { in my English writing } \\
\text { classes. }\end{array}$ & $7 \%$ & $13 \%$ & $10 \%$ & $36 \%$ & $34 \%$ \\
\hline $\begin{array}{l}\text { I keep the grammar } \\
\text { rules in mind when I } \\
\text { am writing in English. }\end{array}$ & $5 \%$ & $16 \%$ & $12 \%$ & $37 \%$ & $30 \%$ \\
\hline $\begin{array}{l}\text { I think that language } \\
\text { practice in real } \\
\text { contexts is more } \\
\text { important than } \\
\text { grammar instruction } \\
\text { in the classroom. }\end{array}$ & $4 \%$ & $7 \%$ & $19 \%$ & $34 \%$ & $36 \%$ \\
\hline
\end{tabular}

Strongly disagree $=1$; disagree $=2$; neutral=3; agree $=4$; strongly agree $=5$ 
The second item was administered in order to elicit students' perceptions on written corrective feedback. As indicated in Table 3, students had a very positive view towards written corrective feedback in L2 writing. Table 3 indicates students' perceptions pf error correction in writing classes.

Table 3. Students' perceptions of error correction in writing classes

\begin{tabular}{l|l|l|l|l|l} 
Questionnaire Item & $\begin{array}{l}\text { Not important at } \\
\text { all }\end{array}$ & Not important & Neutral & Important & Very Important \\
\hline $\begin{array}{l}\text { What is your opinion about } \\
\text { correcting your errors in your } \\
\text { English writings by your } \\
\text { instructor(s)? }\end{array}$ & $0 \%$ & $2 \%$ & $5 \%$ & $60 \%$ & $33 \%$ \\
\hline
\end{tabular}

Not important at all=1; not important=2; neutral=3; important=4; very important=5

In the third item, students were asked to state their perceptions of types of written corrective feedback. As Table 4 shows students' most preferred error types for correction. The responses were consistent with grammar errors $(\mathrm{N}=26)$ as the most popular response followed by vocabulary errors (14), and spelling errors ( $N=3)$. Overall, the students considered grammar as the most important element in their L2 writing.

Table 4. Students' preferences of error correction types

\begin{tabular}{l|l|l|l|l|l} 
Questionnaire Item & Grammar Errors & Vocabulary Errors & Spelling Errors & $\begin{array}{l}\text { Organization } \\
\text { Errors }\end{array}$ & Punctuation Errors \\
\hline $\begin{array}{l}\text { The most preferred } \\
\text { error correction } \\
\text { type }\end{array}$ & $60 \%$ & $33 \%$ & $7 \%$ & $0 \%$ & $0 \%$
\end{tabular}

Item 4 was asked in order to examine students' opinions about teachers' error correction priority. Most of the students $(\mathrm{N}=18)$ preferred their teachers to correct all of their errors. The second popular response $(\mathrm{N}=16)$ was teachers' correcting major errors but not the minor ones. Minority of the students $(\mathrm{N}=9)$ preferred not to be corrected when they make grammatical errors, and preferred teachers to focus on the content only. Table 5 shows students' preferences on teachers' error correction.

Table 5. Students' opinions on teachers' error correction

\begin{tabular}{l|l|l|l|l} 
Questionnaire Item & $\begin{array}{l}\text { My instructor should } \\
\text { correct all errors. }\end{array}$ & $\begin{array}{l}\text { My instructor should } \\
\text { correct major errors but } \\
\text { not the minor ones. }\end{array}$ & $\begin{array}{l}\text { My instructor should } \\
\text { only correct errors that } \\
\text { interfere with } \\
\text { communicating ideas. }\end{array}$ & $\begin{array}{l}\text { My instructor should not } \\
\text { correct grammatical } \\
\text { errors, and should } \\
\text { focus on the content } \\
\text { only. }\end{array}$ \\
& & & \\
\hline
\end{tabular}




\begin{tabular}{l|l|l|l|l}
\hline If there are many errors \\
in your writing, what do \\
you prefer your \\
instructor to do?
\end{tabular}

Item 5 examined the students' preferences of error correction techniques. As Table 6 indicates the most preferred technique was "correcting the error and then providing an explanation for the correction". 39 students out of 43 considered this technique as very useful. The reason of students' preference of this technique most probably stems from their English proficiency level since they need constant explanation as in form of correction when they make errors in their L2 writings. B1 level EFL learners are tend to make more errors since they have just started learning English, as a result they are required to be provided explicit corrective feedback on their $\mathrm{L} 2$ writings. The second error correction type that was preferred by students was "underlining the error and then correcting it". It also shows that students need to be pointed out their errors and need to understand their error.

Table 6. Students' preferences of error correction techniques

\begin{tabular}{|c|c|c|c|c|c|}
\hline $\begin{array}{l}\text { Written Corrective } \\
\text { Feedback } \\
\text { Techniques }\end{array}$ & Very useless & Useless & $\begin{array}{l}\text { Neither useful or } \\
\text { useless }\end{array}$ & Useful & Very useful \\
\hline \multicolumn{6}{|l|}{ Table6 Continued } \\
\hline $\begin{array}{l}\text { Underlining the } \\
\text { error without } \\
\text { correcting it }\end{array}$ & $88 \%$ & $8 \%$ & $0 \%$ & $4 \%$ & $0 \%$ \\
\hline $\begin{array}{l}\text { Underlining the } \\
\text { error and then } \\
\text { directing you to a } \\
\text { source for } \\
\text { information }\end{array}$ & $60 \%$ & $19 \%$ & $6 \%$ & $10 \%$ & $5 \%$ \\
\hline $\begin{array}{l}\text { Indicating the type } \\
\text { of error without } \\
\text { locating or } \\
\text { correcting it }\end{array}$ & $6 \%$ & $54 \%$ & $2 \%$ & $30 \%$ & $8 \%$ \\
\hline $\begin{array}{l}\text { Locating the error } \\
\text { (e.g., by underlying } \\
\text { it) and also } \\
\text { indicating the type } \\
\text { of error }\end{array}$ & $6 \%$ & $27 \%$ & $12 \%$ & $32 \%$ & $23 \%$ \\
\hline $\begin{array}{l}\text { Underlining the } \\
\text { error and then } \\
\text { correcting it }\end{array}$ & $2 \%$ & $3 \%$ & $4 \%$ & $9 \%$ & $82 \%$ \\
\hline $\begin{array}{l}\text { Correcting the error } \\
\text { and then providing } \\
\text { an explanation for } \\
\text { the correction }\end{array}$ & $0 \%$ & $0 \%$ & $5 \%$ & $5 \%$ & $90 \%$ \\
\hline
\end{tabular}




\begin{tabular}{l|l|l|l|l|l}
\hline $\begin{array}{l}\text { Simply indicating } \\
\text { that you have an } \\
\text { error in the } \\
\text { sentence by putting } \\
\text { a cross next to it } \\
\text { without locating or } \\
\text { correcting the error }\end{array}$ & $82 \%$ & $9 \%$ & $9 \%$ & $0 \%$ & $0 \%$ \\
\hline $\begin{array}{l}\text { Asking my } \\
\text { classmate(s) to } \\
\text { correct the errors }\end{array}$ & $45 \%$ & $35 \%$ & $15 \%$ & $2 \%$ & $3 \%$ \\
\hline
\end{tabular}

Very useless $=1$; useless $=2$; neither useful or useless $=3$; useful $=4$; very useful $=5$

As stated above, students need detailed explanations for their errors. Only showing the error or giving the type of error without correcting it is not enough for them. They also did not prefer their friends to correct their errors. This might be because they are aware of each other's' language proficiency and they need correction from their teachers as they see their teachers as more reliable error correction source. The next item was asked to students in order to investigate their opinions of extended comments by teachers on their written assignments. The results showed that students considered extended comments as a very important element of their language learning process (\%90). Their most popular comment type was "comments on grammar" (\%85). On the other hand, "comments on the writing's overall quality" was the least preferred comment type among students (\%82). This is most probably because students at this level usually prefer grammar corrections since they haven't exposed to grammar too much and want to improve their L2 competence. Table 7 indicates students' responses to teachers' extended comments on their L2 writing assignments, and Table 8 indicates their preferences for the type of comment by teachers.

Table 7. Students' responses to teachers' extended comments on their L2 writings

\begin{tabular}{l|l|l|l|l|l} 
Questionnaire Item & Not important at all & Not important & Neutral & Important & Very important \\
\hline $\begin{array}{l}\text { What do you think } \\
\text { when your } \\
\text { teacher(s) writes } \\
\text { extended } \\
\text { comments on your } \\
\text { L2 assignments? }\end{array}$ & $0 \%$ & $0 \%$ & $5 \%$ & $5 \%$ & $90 \%$ \\
\hline
\end{tabular}

Not important at all=1; not important $=2$; neutral $=3$; important $=4$; very important $=5$

Table 8. Students' preferences of type of comment

\begin{tabular}{l|l|l|l|l|l} 
Type of Comment & Very unimportant & Unimportant & Neutral & Important & Very Important \\
\hline Comments on the content & $20 \%$ & $15 \%$ & $45 \%$ & $10 \%$ & $10 \%$ \\
\hline Comments on the grammar & $0 \%$ & $0 \%$ & $5 \%$ & $10 \%$ & $85 \%$ \\
\hline $\begin{array}{l}\text { Comments on the } \\
\text { organization }\end{array}$ & $20 \%$ & $25 \%$ & $22 \%$ & $16 \%$ & $17 \%$ \\
\hline $\begin{array}{l}\text { Comments on the overal } \\
\text { quality of the L2 writing }\end{array}$ & $82 \%$ & $12 \%$ & $6 \%$ & $0 \%$ & $0 \%$
\end{tabular}

The next item was asked to students in order to find out how carefully they would review their teachers' feedback. Most students (33 out of 43) stated that they would read teachers' feedback carefully and correct all errors (Table 9). As claimed above, they need detailed explanations on their errors so that they can see and correct errors in their writings.

Table 9. Students' responses about corrected errors. 


\begin{tabular}{l|l} 
How carefully do you review teachers' correction of errors? & Frequency of Responses \\
\hline I will not read them. & $5 \%$ \\
\hline I will read them, but I won't correct the errors. & $7 \%$ \\
\hline I will read them, and correct the major errors. & $12 \%$ \\
\hline I will read them carefully, and then correct all the errors. & $76 \%$
\end{tabular}

As illustrated above, B1 level EFL learners preferred receiving explicit explanations by their teachers on their errors in L2 writings. They also preferred to receive feedback on all of their errors, mostly on their grammatical errors rather than spelling, punctuation, organization and vocabulary. Since they are new to learn English, they mostly focus on grammar rules to improve their language competence at this level. Most of them also stated that they would care about the extended comments given by teachers and correct their errors after receiving ones.

\section{Discussion and Conclusion}

This study examined the role of corrective feedback in EFL writing classes in a private university's English preparatory school in Istanbul, Turkey. The findings are not so much different from the previous studies in terms of the type of corrective feedback. The findings of the questionnaire showed that students had positive view on written corrective feedback, especially on grammar corrections. They need constant grammar instructions for mastering the writing of English. This derives from their lack of grammar knowledge since they have just started learning L2. They also believed that error correction by teachers is very important, moreover most of them even responded that they would read the comments on their errors carefully and correct all of them. This finding showed that most of these participants really cared about error corrections by their teachers especially on grammar. However, they did not prefer receiving feedback from their peers. This is most probably because their low level of English, and they did not think that they would benefit from peer correction.

The findings of the writing assignment reveal that there is a spectacular difference between the experimental group who received explicit corrective feedback and the control group who received no feedback. In the control group's writing assignments, the number of errors in post and delayed post-test did not change much, while in the experimental group students gradually made less errors compared to the pre-test. They benefited from teacher's comments and error corrections when they completed their writing assignments.

In order to achieve an effective error correction method, teachers should have a clear understanding of the nature of errors. Corder (1967) defines errors as learners' way of testing their understanding about the nature of target language; also they should be perceived with openness and acceptance especially if they are new in learning language. Students' responses to error corrections need to be taken into consideration. Error correction involves both cognitive skills and effective views of language learning, which includes feelings and attitudes.

Both teachers and learners should be open to transform language proficiency from negative productions of learners to positive results. Teachers need to provide necessary facilitations for learners so that learners can benefit from their errors after receiving corrective feedback.

The study has some limitations, for example, the findings were based on data from a small group of students. Also, the generalizability of the findings needed to be endorsed by further research. Further research needs other kinds of instructional contexts in Turkey to empirically test the generalizability of the present findings. Thus, students' background English knowledge should be taken into consideration when investigating their perceptions of corrective feedback. Finally, the present study investigated EFL learners' ratio of errors and perceptions of written corrective feedback in Turkey. Similar studies can also be conducted by language teachers, instructors or researchers in this context.

\section{References}

[1] Amrhein, H. R., \& Nassaji, H. (2010). Written corrective feedback: what do students and teachers prefer and why? Canadian Journal of Applied Linguistics, 13, 95-127.

[2] Bitchener, J., \& Knoch, U. (2009). The contribution of written corrective feedback to language development: A ten-month investigation. Applied linguistics, amp016. 
[3] Carroll, S., \& Swain, M. (1993). Explicit and Implicit Negative Feedback: An Empirical Study of the Learning of Linguistic Generalizations. Studies in Second Language Acquisition, 15(3), 357-386.

[4] Carroll, S., \& Swain, M. (1993). Explicit and Implicit Negative Feedback: An Empirical Study of the Learning of Linguistic

[5] Generalizations. Studies in Second Language Acquisition, 15(3), 357-386.

[6] Carroll, S. (2001). Input and evidence: The raw material of second language Acquisition. Amsterdam: Benjamins.

[7] Chen, S., Nassaji, H. \& Liu, Q. (2016). Asian-Pacific Journal of Second and Foreign Language Education 1:5.

[8] Corder, S. P. (1967). The significance of learner's errors. IRAL-International Review of Applied Linguistics in Language Teaching, 5(1-4), 161-170.

[9] Correa Pérez, R., Martínez Fuentealba, M., Molina De La Barra, M., Silva Rojas, J., \& Torres Cisternas, M. (2013). The Impact of Explicit Feedback on EFL High School Students Engaged in Writing Tasks. Profile Issues in Teachers' Professional Development, 15(2), 149-163.

[10] Ellis, R. (2009). Corrective Feedback and Teacher Development. L2 Journal, Volume 1, pp. 3-18

[11] Kim, H. R., \& Mathes, G. (2001). Explicit vs. implicit corrective feedback. The Korea TESOL Journal, 4(1), 5772.

[12] Kirgoz, Y., Agcam, R. (2015). Teachers' Perceptions on Corrective Feedback in Turkish Primary Schools, Procedia-Social and Behavioral Sciences, 192, 574-581.

[13] Gholami, J. \& Talebi, Z. (2012) The Effects of Implicit and Explicit Feedback on EFL Learners' Grammatical Accuracy; The Case of Regular Past Tense in English, International Journal of Physical and Social Sciences, Volume 2, Issue 6, 39-62.

[14] Lyster, R. \& Ranta, L. (1997). Corrective Feedback and Learner Uptake: Negotiation of Form in Communicative Classrooms. Cambridge University Press, SSLA, 37-66.

[15] Russell, J., \& Spada, N. (2006). The effectiveness of corrective feedback for the acquisition of L2 grammar. A metaanalysis of the research. In J. M. Norris \& L. Ortega (Eds.), Synthesizing research on language learning and teaching (pp. 133-164). Amsterdam: John Benjamins Publishing Company.

[16] Truscott, J. (1996). The case against grammar correction in L2 writing classes. Language Learning, 46(2), 327369.

[17] Truscott, J. (1999). The case for "The case against grammar correction in L2 writing classes": A response to Ferris. Journal of Second Language Writing, 8, 111-122.

[18] Truscott, J. (2007). The effect of error correction on learners' ability to write accurately. Journal of Second Language, Writing, 16, 255-272.

[19] Ulgu, S., Sari I., \& Griffiths C. (2013). Error Correction in Language Teaching: The Teachers' Perspective. International Journal of Arts \& Sciences, 6(3), 229-241.

[20] Varnosfadrani, A. D., \& Basturkmen, H. (2009). The effectiveness of implicit and explicit error correction on learners' performance. System, 37(1), 82-98.

[21] Voerman, L., Meijer, P. C., Korthagen, F. A. J. \& Simons, R. J. (2012). Types and frequencies of feedback

[22] interventions in classroom interaction in secondary education. Teaching and Teacher Education 28 2012) 11071115. 